\title{
Furfural Synthesis from Mikania mircantha using Sulfonated Carbon Catalyst Derived from Candlenut Shell
}

\author{
Taslim*, Fitri Hardianti Sinaga, Iriany and Ferry Irawan \\ Department of Chemical Engineering, Faculty of Engineering, Universitas Sumatera Utara, Medan 20155, Indonesia.
}

Taslim-ORCID: 0000-0003-0482-320X; Iriany-ORCID: 0000-0001-8963-551X

\begin{abstract}
Candlenut shell is an agricultural solid waste which can be utilized for low cost active carbon. The aim of this work was to examine candlenut shell as a carbon source for catalyst support, its modification with sulfuric acid, as well as its application in furfural synthesis. Mikania mircantha was used as a feedstock. Candlenut shell was carbonized at $350^{\circ} \mathrm{C}$ for $4 \mathrm{~h}$ in a furnace. The carbon obtained was modified with sulfuric acid solution, followed by drying. The activated carbon formed was characterized by SEM-EDX, FTIR, and acid density test $/ \mathrm{H}^{+}$ activity. Sulfonated carbon was utilized as solid catalyst in the hydrolysis reaction for furfural production. The reaction was conducted in a batch reactor at $100-120^{\circ} \mathrm{C}$, catalyst load of $30-$ $40 \%$, and reaction time of $0-140 \mathrm{~min}$. The highest furfural yield achieved was $8.7 \%$ at $110^{\circ} \mathrm{C}$, reaction time of 120 minutes, and catalyst loading of $40 \%$ by weight. The results confirmed that candlenut shell based activated carbon is applicable as a solid catalyst in furfural synthesis.
\end{abstract}

Keywords: Candlenut shell, carbonization, sulfonation, hydrolysis, furfural yield

\section{INTRODUCTION}

Several lignocellulosic biomass can be used as feedstock to produce furfural such as rice husk, bagasse, corn cob, and wheat bran [1]. Lignocellulosic biomass contain 42-45\% cellulose, $22-28 \%$ lignin, and 23-36\% hemicellulose [2]. As the second largest content after cellulose, hemicellulose is the main material in synthesizing furfural. The most common type of hemicellulose is xylan, which is the polymer of pentose sugar (xylose) found in dicotyledonous plants such as Mikania micrantha $(\mathrm{MM})[3]$.

MM is one of the most rampant weed species in the world because of its rapid growth, covering other plants around it, leading to sunlight deficiency and death of other plants [4]. The main chemical composition of MM are pentosan, holocellulose, and lignin, about $56.04 \pm 0.86 \%, 14.05 \pm 0.18 \%$, and $23.54 \pm$ $0.89 \%$ respectively [3]. Using MM as a furfural precursor is very potential because of the highest pentosan content of all biomass. As one of the furan derivatives, furfural can be produced from the hemicellulose fraction of lignocellulose, is considered a promising biochemical-based commodity because of its use in the production of several products such as fuel additives, antacids, paints, fertilizers, and various other products that are usually produced from non-renewable resources [5].

Production of furfural from lignocellulosic biomass through hydrolysis of biomass rich in pentosan and followed by dehydration of pentose using acid catalyst, is shown in the following equation [6]:

$$
\begin{aligned}
& \underset{\text { pentosans }}{\left(\mathrm{C}_{5} \mathrm{H}_{8} \mathrm{O}_{4}\right)_{\mathrm{n}}}+\mathrm{nH}_{2} \mathrm{O} \rightarrow \mathrm{nC}_{5} \mathrm{H}_{10} \mathrm{O}_{5} \\
& \mathrm{nC}_{5} \mathrm{H}_{10} \mathrm{O}_{5} \rightarrow \\
& \text { pentoses }
\end{aligned}
$$

The catalyst commonly used is homogeneous acid in the form of inorganic acid such as sulfuric acid, phosphoric acid, and hydrochloric acid. However, the use of inorganic acid catalyst can cause corrosion in the reactor, difficulty in separating reaction products, and is not environmentally friendly [7]. On the other hand, the use of organic acid catalysts has been carried out, but the furfural yield obtained is still low [8,9]. Therefore, the use of carbon-based solid acid catalyst deserves consideration [10].

For carbon solid acids catalyst formation, carbon material generally comes from biomass. For this purpose, candlenut shells can be considered as a source of activated carbon. As a catalyst support, activated carbon has many pores, large surface area, able to withstand high temperature and pressure, easy to recycle, and cheap. The carbon used must be in the form of polyaromatic hydrocarbon. Such structure occurs when the biomass carbonation is carried out at a temperature of about $400^{\circ} \mathrm{C}$ [11]. The carbon formed is sulfonated with sulfuric acid to produce sulfonated carbon. The sulfonate groups have $\mathrm{H}^{+}$ which acts like acid and attaches to aromatic structures [12]. Using solid acid catalyst has several advantages such as easier separation from the reaction product through filtration, reusable, does not corrode the equipment, and more environmentally friendly. In addition, carbon solid acids have high $-\mathrm{SO}_{3} \mathrm{H}$ density, high surface activity, and better thermal stability which is a very potential catalyst to convert pentose into furfural [10]. 
Research into the utilization of carbon active as catalyst support in biomass hydrolysis has received much attention in recent years, but research has so far been concentrated on carbon derived from bamboo [10], Jatropha Curcas [13], palm kernel shells [14], bagasse [15], corn stover [16], pine chips [17]. So far, the utilization of candlenut shells as carbon source for catalyst support in furfural formation has never been conducted. Therefore, the research objective was to evaluate candlenut shells as carbon precursor in solid acid catalyst formation and its application in the furfural synthesis.

\section{MATERIALS AND METHODS}

\section{II.1. MATERIALS}

Candlenut shells and MM were collected from Medan Selayang, Indonesia. Chemical used were sulfuric acid, Rochelle salt, barium chloride, sodium hydroxide, acetic acid, chloroform, aniline supplied by CVA Medan.

\section{II.II. CATALYST PREPARATION}

The candlenut shell was washed under running water to remove dirt on the surface. Then the shell were heated in an oven at $110^{\circ} \mathrm{C}$ for 2 hours, followed by carbonization in a furnace at $350^{\circ} \mathrm{C}$ for 4 hours [7]. The carbon obtained was crushed and sieved with a 50 mesh sieve. Five grams of carbon was placed in a beaker glass and $50 \mathrm{ml}$ of $96 \% \mathrm{H}_{2} \mathrm{SO}_{4}$ was added and stirred at $250 \mathrm{rpm}$ for 15 minutes. Carbon containing $\mathrm{H}_{2} \mathrm{SO}_{4}$ was placed in a ceramic container and heated for 6 hours at $120^{\circ} \mathrm{C}$ to produce the catalyst. Then the catalyst was cooled and washed with deionized water at $90^{\circ} \mathrm{C}$ until no sulfate was detected using $\mathrm{BaCl}_{2}$. The catalyst was dried at $110^{\circ} \mathrm{C}$ for 24 hours. Catalyst was analyzed for its morphology and composition, functional groups, and acid density by SEMEDX, FTIR, and titration respectively.

\section{II.III. MM POWDER PREPARATION}

The mixture of leaves and stems of MM was washed to remove all dissolved impurities. MM was cut into small pieces of $1 \mathrm{~cm}$ using a knife, dried in an oven for $2-3$ hours at $105^{\circ} \mathrm{C}$, crushed in a ball mill, sieved to a size of 70 mesh [8], and stored in a tightly closed plastic container.

\section{II.IV. FURFURAL SYNTHESIS}

Synthesis furfural was done according to Taslim et al. and Li et al. $[8,10]$ with modification. As much as $25 \mathrm{~g}$ dry powder MM, $25 \mathrm{~g}$ sodium chloride were introduced into a stainless steel batch reactor and then mixed with $7.5 \mathrm{~g}$ carbon solid acid catalyst and $700 \mathrm{ml}$ of water. The reactor was equipped with a condenser to condense furfural vapor. The reaction was carried out at $100-120^{\circ} \mathrm{C}$ for $0-140 \mathrm{~min}$. The liquid product of crude furfural was collected and filled into a separator funnel. The crude furfural was extracted by adding $50 \mathrm{ml}$ chloroform and allowed to form two layers. The upper layer was rich in water, and the lower layer was rich in furfural and chloroform. The furfural was separated from chloroform by distillation at $70^{\circ} \mathrm{C}$. For comparison purpose, the same procedure was repeated but using $250 \mathrm{ml}$ of $20 \%$ sufuric acid. The furfural formed was identified by FTIR and GC-MS.

\section{RESULTS AND DISCUSSION}

\section{III.1. PRELIMINARY ANALYSIS OF MM}

Based on early analysis in this work, the mixture of leaves and stems of MM had an average water content $84.5 \%$, and average pentosan content of $53.6 \%$. The pentosan content is very close to that in other literature at $\pm 56.04 \%$ [3] .

\section{III.II. SEM-EDX ANALYSIS}

Fig 1 shows the surface morphology of candlenut shell powder using SEM. The powder has irregular shape, uneven, and nonporous surface. These phenomena is also reported by other researchers $[7,18,19]$. This situation indicates that the powder has small surface area.

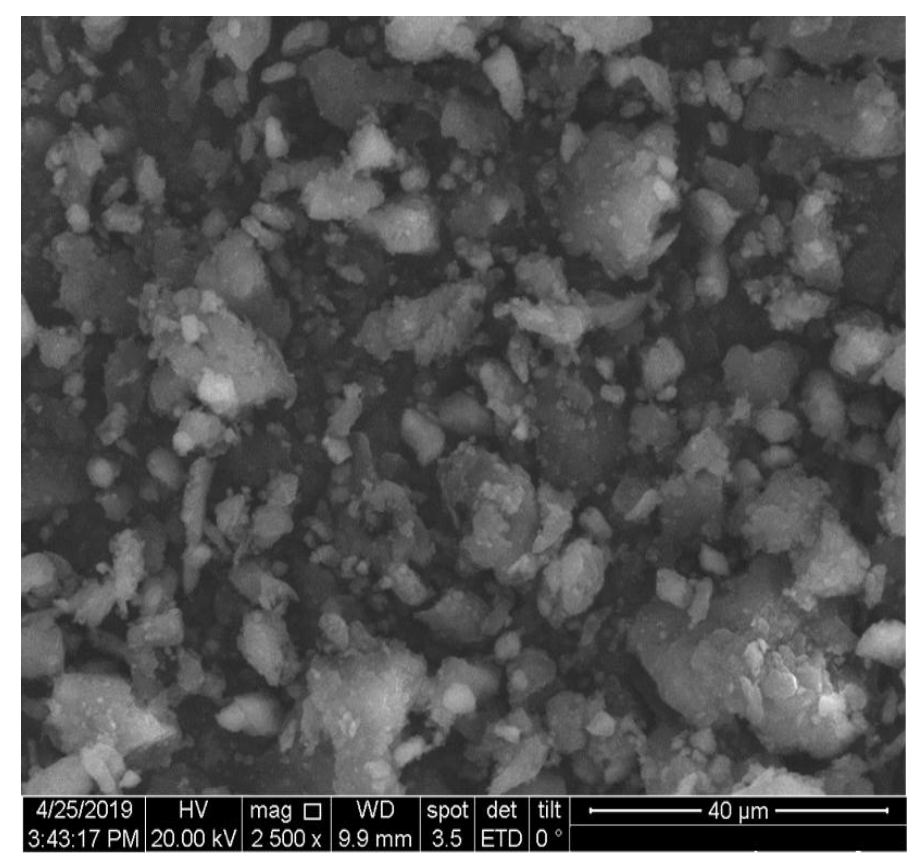

Fig 1. Candlenut shell powder

Carbon from candlenut shell powder after carbonization at $350^{\circ} \mathrm{C}$ for 4 hours was observed using SEM and the results is depicted in fig 2. During carbonization, carbon content increased while organic compounds in candlenut shell such as cellulose, hemicellulose, lignin and other extractive matters decomposed and produced gas products. Consequently, pores are formed and surface area increases. The pore formation plays an important role in sulfonate groups uptake during sulfonation, because sulfonate groups adhere to the pore surface. 


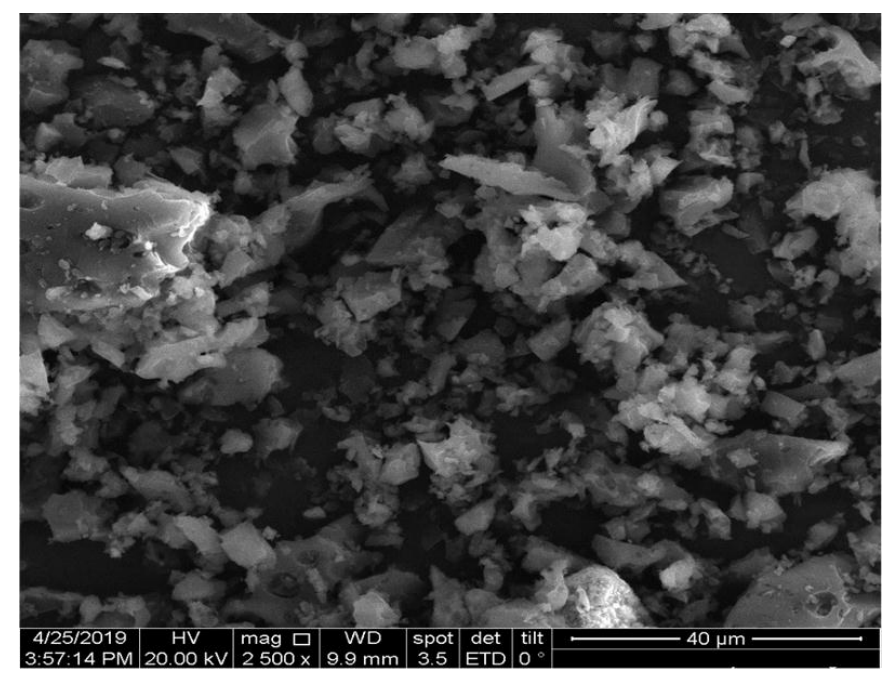

Fig 2. Carbon derived from candlenut shell

Fig 3 presents carbon morphology after sulfonation at $120^{\circ} \mathrm{C}$ for $6 \mathrm{~h}$. Chemical treatment on candlenut shell changes its structure. The morphology of carbon was modified after sulfonation. Sulfonate groups were adsorbed and dispersed on carbon surface and it penetrated in the pore channels. Drying after sulfonation will vaporize volatile matters and strengthen sulfonate groups bounds on carbon surface.

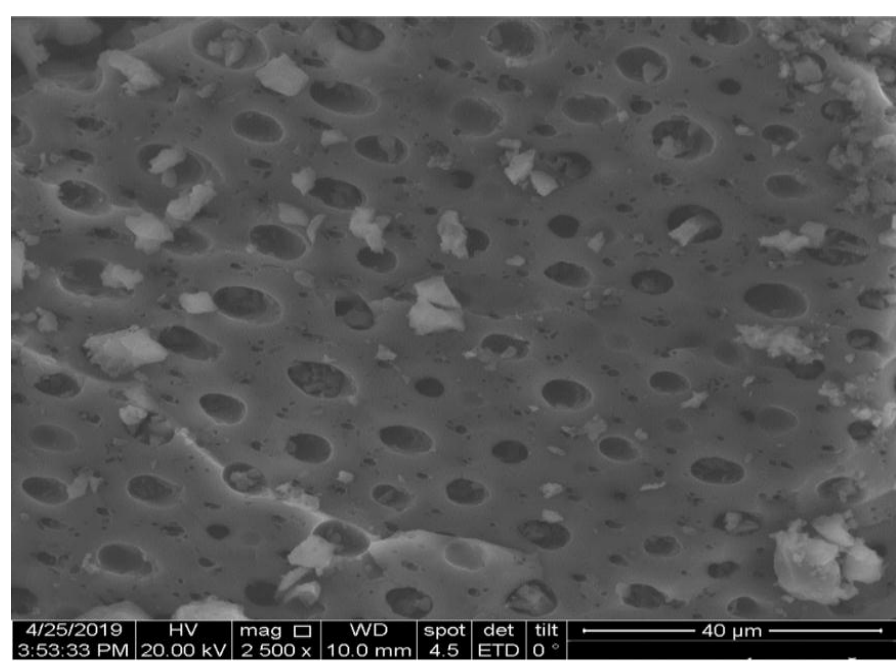

Fig 3. Sulfonated carbon

EDX analysis was conducted on candlenut shell, carbon and sulfonated carbon. The results are displayed in table 1. Initially, candlenut shell contained $43.86 \% \mathrm{C}$ and $47.81 \% \mathrm{O}$. Carbon and oxygen elements dominated over other elements. During carbonization, carbon atoms will coalesce and form more stable bonds while other elements may break off the bond or evaporate [20]. As a result, carbon content increased while oxygen content decreased after carbonization. After sulfonation, sulfur content was tracked at $5.29 \%$. This indicated that sulfonate groups had adsorbed on carbon surface.
Table 1. Composition of candlenut shell powder, carbon and sulfonated carbon

\begin{tabular}{cccc}
\hline Element & $\begin{array}{c}\text { Candlenut shell } \\
(\%)\end{array}$ & $\begin{array}{c}\text { Carbon } \\
(\%)\end{array}$ & $\begin{array}{c}\text { Sulfonated } \\
\text { carbon }(\%)\end{array}$ \\
\hline $\mathrm{C}$ & 43.86 & 66.29 & 63.86 \\
$\mathrm{O}$ & 47.81 & 28.92 & 27.90 \\
$\mathrm{Ca}$ & 6.73 & 4.79 & 2.32 \\
$\mathrm{Mg}$ & 1.60 & - & - \\
$\mathrm{S}$ & - & - & 5.92 \\
\hline
\end{tabular}

\section{III.III. EFFECT OF REACTION TIME ON FURFURAL YIELD AT VARIOUS TEMPERATURES}

Figure 4 shows the effect of reaction time and temperature on the furfural yield at a concentration of $40 \%$ by weight of the sulfonated carbon catalyst. At a temperature of $100{ }^{\circ} \mathrm{C}$ the furfural yield begins to form at 30 minutes and reaches a peak at 120 minutes with a yield of $6.5 \%$ and decreases in the following minutes. In fig 4 , it can be seen that the best furfural yield is at $110^{\circ} \mathrm{C}$. At temperature of $120^{\circ} \mathrm{C}$, furfural formation begins at 10 minutes. The increase in reaction time caused the yield to increase to a peak of $7.3 \%$ at 90 minutes, then the yield decreased as reaction time increased. For the reaction temperature of $110^{\circ} \mathrm{C}$ furfural was formed after 20 minutes, and the highest yield was $8.7 \%$, which was obtained after 120 minutes, which then decreased with increasing time. At a temperature of $120^{\circ} \mathrm{C}$, it was observed that the evaporation rate of water was higher than the temperatures of 100 and $110^{\circ} \mathrm{C}$. As mentioned in equations 1 and 2, the hydrolysis of pentosan in acidic conditions requires water, while pentose dehydration releases water. If the rate of evaporation of water is too fast, the hydrolylis of pentosan will become imperfect, causing less pentose to be formed. As a consequence, the furfural yield is also low. As reported by Rao et al. [21] that an increase in temperature will also affect the increase in furfural yield, but with the increasing temperature it will cause degradation in furfural formation and produce byproducts.

From fig 4 it can be seen that with constant reaction temperature, increasing reaction time can causes better contact between reactants, therefor increasing the furfural yield. However, if the reaction time is too long and the temperature is too high, it will cause the furfural yield to decrease. This is because furfural cannot last long in acidic conditions at high temperatures and for a long time, side products will form. This was also reported by Li et al. [22] where the furfural formation increased until the $120^{\text {th }}$ minute and the furfural yield became constant after the $120^{\text {th }}$ minute. The same results were reported by Guche et al. [23], that furfural yield will increase with reaction time. After a certain time, an increase in time will lead to a reduction in furfural yield due to side reactions. As reported by Liu et al. [22], furfural degradation can form small molecules and cations, causing furfural to undergo a 
International Journal of Engineering Research and Technology. ISSN 0974-3154, Volume 13, Number 10 (2020), pp. 2546-2552

(C) International Research Publication House. https://dx.doi.org/10.37624/IJERT/13.10.2020.2546-2552

condensation reaction with xylose to form insoluble polymers such as humin.

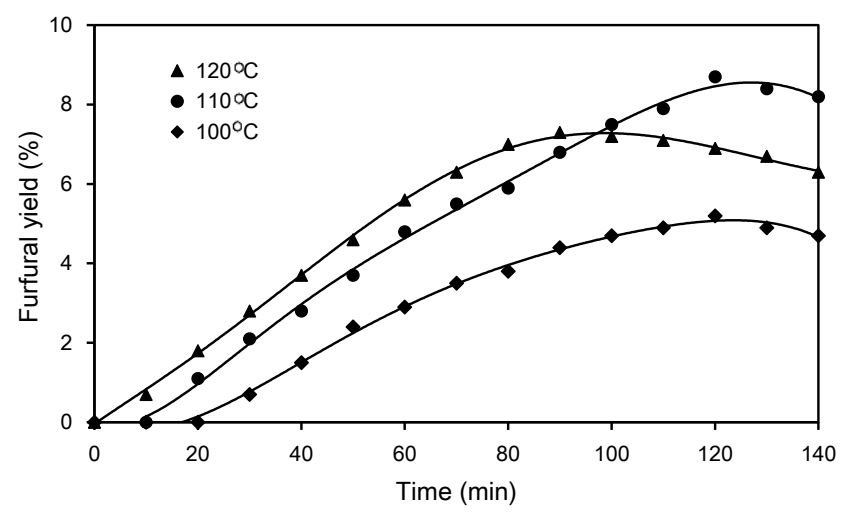

Fig 4. Effect of reaction time on furfural yield at various temperatures and $40 \%$ catalyst concentration.

\section{III.IV. EFFECT OF REACTION TIME ON FURFURAL YIELD AT VARIOUS CATALYST CONCENTRATIONS}

In this study, the concentrations of sulfonated carbon catalyst used were 30 and $40 \%$, and $20 \%$ sulfuric acid catalyst was used as a comparison. Furfural yield is strongly influenced by the concentration of the catalyst used as shown in fig 5. Increasing the concentration of the sulfonated carbon catalyst from 30 to $40 \%$ can increase the yield of furfural. In general, increasing the catalyst concentration in the production of furfural can improve the contact area between the reactants and the catalyst molecule, causing the conversion of pentosan (hemicellulose) becomes higher. As reported by Luo et al. [24] the addition of catalyst can accelerate the breakdown of inter and intra bonds in the reaction. This can promote the selective breakdown of hemicellulose and facilitate furfural formation.

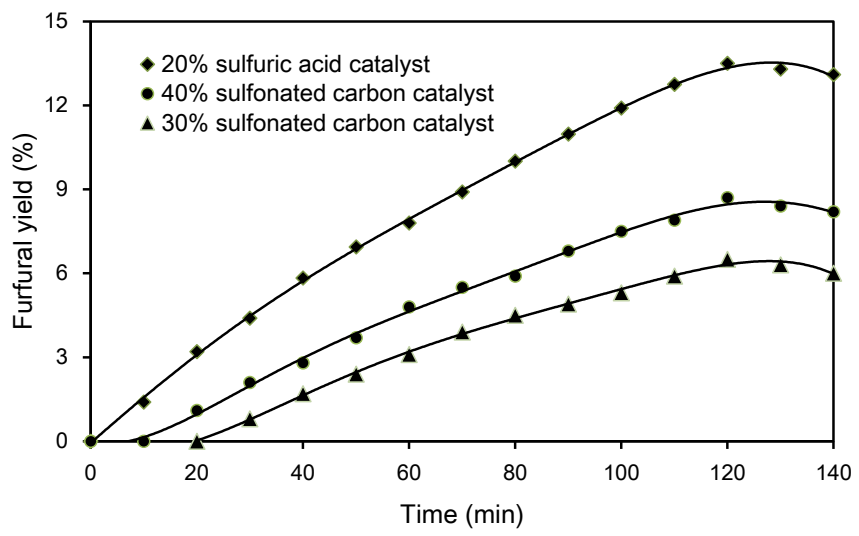

Fig 5. Effect of reaction time on furfural yield at various catalyst concentration and $110^{\circ} \mathrm{C}$ reaction temperature.

Fig 5 shows that the furfural yield using sulfonated carbon catalyst is lower than using sulfuric acid catalyst. This is related to the difference in acidity or $\mathrm{H}^{+}$activity of the two types of catalysts used. The $\mathrm{H}^{+}$value of each catalyst used can be seen in table 2.

Table 2. $\mathrm{H}^{+}$activity or acidity of catalyst

\begin{tabular}{lccc}
\hline \multicolumn{1}{c}{ Catalyst } & $\begin{array}{c}\text { Concentration } \\
(\%)\end{array}$ & $\begin{array}{c}\mathrm{H}^{+} \text {activity } \\
\text { or } \\
\text { Acidity of catalyst } \\
(\mathrm{mmol} / \mathrm{g})\end{array}$ & $\begin{array}{c}\text { Highest } \\
\text { Yield } \\
(\%)\end{array}$ \\
\hline Sulfonated carbon & 30 & 4.88 & 6.5 \\
Sulfonated carbon & 40 & 4.88 & 8.7 \\
Sufuric acid & 20 & 200.04 & 13.5 \\
\hline
\end{tabular}

At the same temperature, furfural formation with $20 \%$ sulfuric acid catalyst was faster than making furfural with sulfonated carbon catalyst, this is because the $\mathrm{H}^{+}$value of sulfuric acid is higher than the $\mathrm{H}^{+}$value of sulfonated carbon. Furfural formation with sulfuric acid catalyst began to form at the $10^{\text {th }}$ minute, and continued to increase with time until the $120^{\text {th }}$ minute with the highest yield of $13.5 \%$. In addition, sulfonated carbon is a solid catalyst that generally causes mass transfer resistance, and also influences furfural formation. As a result, the furfural yield obtained is lower than the use of sulfuric acid catalyst.

\section{III.V. FURFURAL ANALYSIS}

\section{III.V.I. FTIR Analysis}

FTIR analysis to determine functional groups was needed to confirm that the resulting distillate was furfural. The results of FTIR analysis can be seen in Figure 6. Based on FTIR analysis, the aldehyde functional groups in furfural compounds were identified by the presence of C-H stretching vibrations (2900$2700)$ and $\mathrm{C}=\mathrm{O}(1740-1620)$ at peak of $2870 \mathrm{~cm}^{-1}$ and $1681 \mathrm{~cm}^{-}$ ${ }^{1}$ for both sulfonated carbon catalyst and sulfuric acid catalyst. Meanwhile, the presence of $\mathrm{C}-\mathrm{H}$ aromatic function is absorbed in the area (3060-3010) with $3020 \mathrm{~cm}^{-1}$ peak. The $\mathrm{C}=\mathrm{C}$ aromatic group (1620-1560 $\left.\mathrm{cm}^{-1}\right)$ was shown at a vibration peak of $1567.8 \mathrm{~cm}^{-1}$, and the $\mathrm{C}-\mathrm{O}-\mathrm{C}$ group is absorbed in the $1040-1070 \mathrm{~cm}^{-1}$ region with evidence at vibration peak of 1070 $\mathrm{cm}^{-1}$. The vibration values obtained in this study are very close to those reported in the literature $[8,9]$.

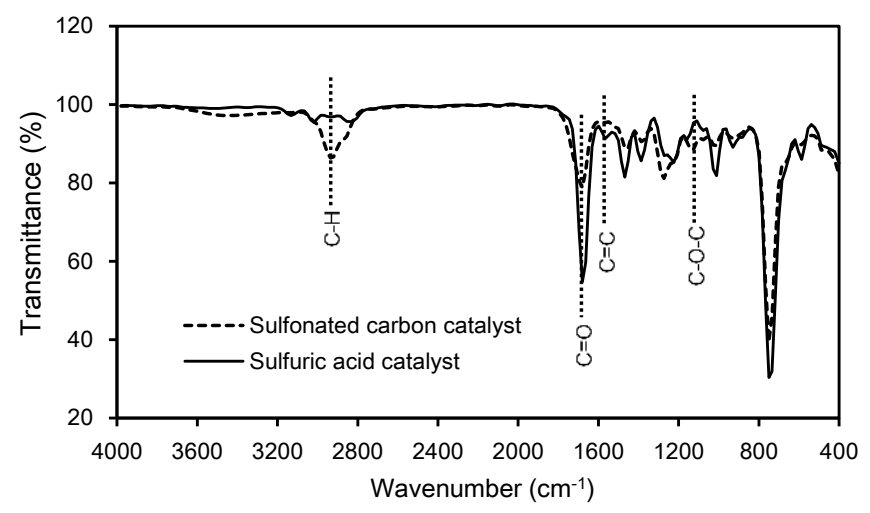

Fig 6. FTIR analysis using sulfonated carbon and sulfuric acid catalyst 
By comparing the vibration values obtained with the standard furfural vibration values which are shown in table 3 [25], it can be confirmed that the compound produced from MM hydrolysis was furfural. To strengthen the results obtained, the analysis was also carried out with GC-MS.

Tabel 3. Standard furfural vibration

\begin{tabular}{lc}
\hline Vibration & Standard furfural $\left(\mathrm{cm}^{-1}\right)$ \\
\hline C-H aromatic streching & $3060-3010$ \\
C-H aldehyde Streching & $2900-2700$ \\
C $=$ O aldehyde streching & $1740-1620$ \\
C $=$ C aromatic streching & $1620-1560$ \\
C-O-C streching & $1140-1070$ \\
\hline
\end{tabular}

\section{III.V. II. GC-MS Analysis}

GCMS analysis result of the furfural is shown in fig 7 and 8 .

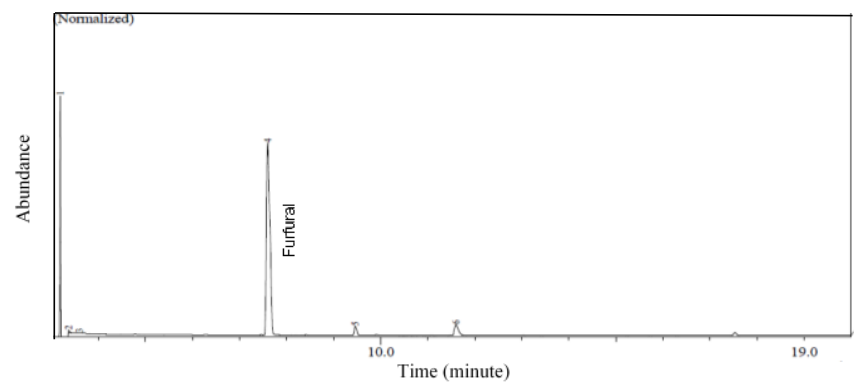

(a)

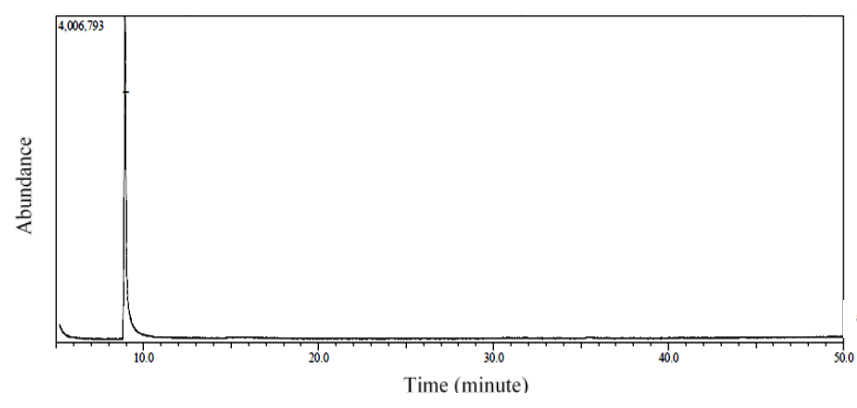

(b)

Fig 7. GC analysis of furfural catalyzed by (a) sulfonated carbon, (b) sulfuric acid

Based on fig 7, the results of GC analysis shows the quantity of furfural compound in MM hydrolysis result. This is shown at peak 4 (fig 7a) with a retention time of 7.58 minutes and a percent area of $60.35 \%$ for a sulfonated carbon catalyst, while for a sulfuric acid catalyst $20 \%$ is shown at peak 1 with a retention time of 8.975 minutes and a percent area of $100 \%$ (fig 7b)
Meanwhile, mass spectroscopy result is used to determine the molecular weight of a chemical compound and it is useful to determine the molecular structure based on the resulting fragmentation pattern. The mass spectroscopy result of GC-MS is shown in Figure 8.

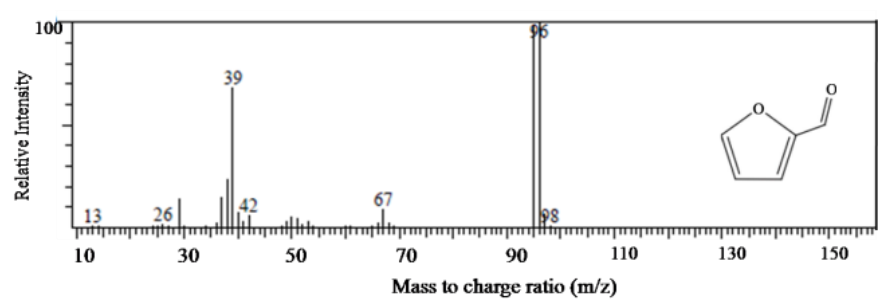

(a)

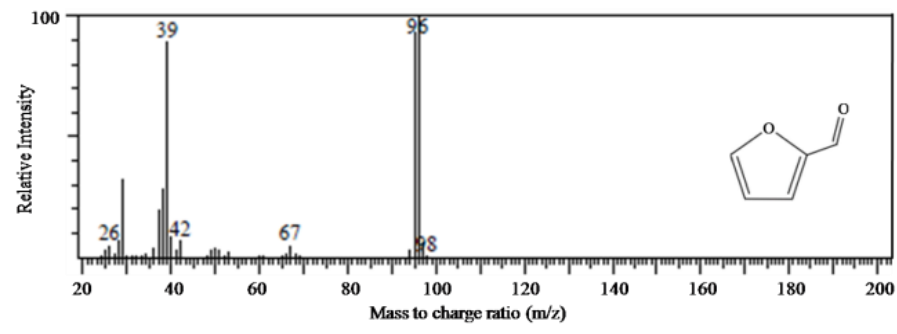

(b)

Fig 8. Mass spectroscopy analysis of furfural catalyzed by (a) sufonated carbon, (b) sulfuric acid

The results of mass spectroscopic analysis for furfural using both sulfonated carbon and sulfuric acid show ion fragmentation at mass/charge ratio $(\mathrm{m} / \mathrm{z}) 26,39,42,67,96$, and 98. The molecular ion peak at $\mathrm{m} / \mathrm{z}=96$ is for furfural. This $\mathrm{m} / \mathrm{z}$ values are suitable to the standard furfural $\mathrm{m} / \mathrm{z}$ value. The standard furfural $\mathrm{m} / \mathrm{z}$ values can be seen in table 4 [26].

Table 4. Standard furfural $\mathrm{m} / \mathrm{z}$ values

\begin{tabular}{ccccc}
\hline Compound & $\mathrm{m} / \mathrm{z}$ & $\begin{array}{c}\text { Relative } \\
\text { Intensity (\%) }\end{array}$ & $\mathrm{m} / \mathrm{z}$ & $\begin{array}{c}\text { Relative } \\
\text { Intensity (\%) }\end{array}$ \\
\hline \multirow{5}{*}{ Furfural } & 97 & 6 & 41 & 14 \\
& 96 & 100 & 40 & 5.9 \\
& 95 & 88.6 & 39 & 56.2 \\
& 68 & 1.5 & 38 & 14.3 \\
& 67 & 5.8 & 37 & 8.5 \\
& 53 & 1.0 & 36 & 56.2 \\
& 51 & 21.6 & 29 & 14.3 \\
& 50 & 2.5 & 28 & 3.9 \\
& 49 & 1.3 & 26 & 1.7 \\
& 42 & 4.7 & 14 & 1.0 \\
\hline
\end{tabular}

Ion fragmentations at $\mathrm{m} / \mathrm{z} 26,39,42,67,96$, and 98 show the breakdown of furfural into several fragments. Each $\mathrm{m} / \mathrm{z}$ 
International Journal of Engineering Research and Technology. ISSN 0974-3154, Volume 13, Number 10 (2020), pp. 2546-2552

(C) International Research Publication House. https://dx.doi.org/10.37624/IJERT/13.10.2020.2546-2552

represents one element. The fragmentation patterns and element names produced by the two catalysts used in this study are shown in table 5 .

Table 5. Fragmentation patterns

\begin{tabular}{lcl}
\hline Compound & $\mathrm{m} / \mathrm{z}$ & Element \\
\hline & 96 & $\mathrm{C}_{5} \mathrm{H}_{4} \mathrm{O}_{2}{ }^{+}$(furfural) \\
& 67 & $\mathrm{C}_{4} \mathrm{H}_{3} \mathrm{O}(2$-furyl $)$ \\
Furfural & 42 & $\left(\mathrm{C}_{2} \mathrm{H}_{2} \mathrm{O}\right)^{+}$(ketene) \\
& 39 & $\mathrm{C}_{3} \mathrm{H}_{3}{ }^{+}$(cyclopropenyl) \\
& 26 & $\mathrm{C}_{2} \mathrm{H}_{2}{ }^{+}$(acetylene) \\
\hline
\end{tabular}

Initially the furfural cation $\left(\mathrm{C}_{5} \mathrm{H}_{4} \mathrm{O}_{2}{ }^{+}, \mathrm{m} / \mathrm{z}=96\right)$ will dissociate to form the following ions such as $\mathrm{C}_{4} \mathrm{H}_{3} \mathrm{O}^{+}(\mathrm{m} / \mathrm{z}=67), \mathrm{C}_{3} \mathrm{H}_{3}{ }^{+}$ $(\mathrm{m} / \mathrm{z}=39), \mathrm{C}_{2} \mathrm{H}_{2} \mathrm{O}^{+}(\mathrm{m} / \mathrm{z}=42)$, and $\mathrm{C}_{2} \mathrm{H}_{2}{ }^{+}(\mathrm{m} / \mathrm{z}=26)$. The decomposition mechanism begins when the furfural ion $\mathrm{C}_{5} \mathrm{H}_{4} \mathrm{O}_{2}{ }^{+}(\mathrm{m} / \mathrm{z}=96)$ splits into the first fragment, the $\mathrm{C}_{4} \mathrm{H}_{3} \mathrm{O}^{+}$ ion $(\mathrm{m} / \mathrm{z}=67)$ due to the loss of $\mathrm{CO}$ group and the $\mathrm{C}_{3} \mathrm{H}_{3}{ }^{+}$ion $(\mathrm{m} / \mathrm{z}=39)$ which is formed due to the loss of $\mathrm{C}_{2} \mathrm{H}_{2}{ }^{+}$. Then the $\mathrm{C}_{2} \mathrm{H}_{2} \mathrm{O}^{+}$cation $(\mathrm{m} / \mathrm{z}=42)$ appears as continuation of the dissociation of $\mathrm{C}_{4} \mathrm{H}_{3} \mathrm{O}^{+}$ion $(\mathrm{m} / \mathrm{z}=67)$. The minor ion $\mathrm{C}_{2} \mathrm{H}_{2}{ }^{+}$ $(\mathrm{m} / \mathrm{z}=26)$ is formed due to the loss of $\mathrm{C}_{3} \mathrm{H}_{3}{ }^{+}$as a continuation of the fragment dissociation of the $\mathrm{C}_{4} \mathrm{H}_{3} \mathrm{O}^{+}$ion $(\mathrm{m} / \mathrm{z}=67)$ [27].

\section{CONCLUSIONS}

The evaluation of sulfonated carbon catalyst derived from candlenut shell for furfural synthesis of $\mathrm{MM}$ has been successfully carried out. The highest furfural yield of $8.7 \%$ was achieved at 120 minutes, the reaction temperature was $110^{\circ} \mathrm{C}$, and the amount of catalyst used was $40 \%$ by weight. FTIR analysis result shows the presence of $\mathrm{C}-\mathrm{H}$ and $\mathrm{C}=\mathrm{O}$ aldehyde functional groups were traced to wavenumber of 2870 and 1681 $\mathrm{cm}^{-1}$. GCMS test results shows that furufural compound were detected at retention time of 7.58 minutes with $60.35 \%$ percent area for sulfonated carbon catalyst, and retention time of 8.975 minutes with $100 \%$ percent area of for $20 \%$ sulfuric acid catalyst. The $\mathrm{m} / \mathrm{z}$ value obtained was 96 according to the furfural standard.

\section{REFERENCES}

[1] G. Machado, S. Leon, F. Santos, R. Lourega, J. Dullius, M.E. Mollmann, and P. Eichler. Literature review on furfural production from lignocellulosic biomass, Natural Resources, 7, 2016, 115-129.

[2] L. Senila, M. Miclean, M. Senila, M. Roman, dan C. Roman. New analysis method of furfural obtained from wood applying an autohydrolysis pretreatment. Romanian Biotechnological Letters, 18(1), 2013, 79477955.

[3] C.H. Ko, T.L. Shih, B.T. Jhan, F.C. Chang, Y.N. Wang, dan Y.C. Wang. Production of xylooligosaccharides from forest waste by membrane separation and Paenibacillus xylanase hydrolysis. BioResources, 8(1, 2013, 612-627.
[4] A. Matawali, L.P. Chin, H.S. Eng, and J.A. Gansau, Antibacterial and Phytochemical Investigation of Mikania micrantha H.B.K. (Asteraceae) from Sabah, Transactions on Science and Technology, 3(1-2), 2016, 244-250.

[5] Jeon W, Ban C, Eun J, Chul H and Heui D, A chemical production of furfural from macroalgae-derived alginic acid over. J. Molecular Catalysis, 423, 2016, 264-269.

[6] Taslim, Iriany, O. Bani, A.W. Sinaga, Furfural synthesis from mile-a-minute weed (Mikania micrantha) using roselle petal extract as catalyst, Proceedings of the $1^{\text {st }}$ International Conference on Chemical Science and Technology Innovation (ICOCSTI 2019), SCITEPRESS - Science and Technology Publication, Lda, 2020, 21-25

[7] Taslim, D.H. Batubara, S. Maulina, Iriany, and O. Bani, Preparation and characterization of sulfonated carbon from candlenut shell as catalyst for hydrolysis of cogon grass cellulose into glucose, Asian Journal of Chemistry, 32 (6), 2020, 1404-1408.

[8] Taslim, Mirnandaulina M., Iriany, and Tambun, R., Furfural production from mile-a-minute weed (Mikania micrantha) using organic acid from bilimbi (Averrhoa bilimbi), Asian Journal of Chemistry, 30 (5), 2018, 107 111.

[9] Taslim, S. Pratiwi, A.W. Sinaga, and Iriany, Furfural synthesis from Mikania micrantha using tamarind extract as catalyst, International Journal of Engineering Research and Technology, 13 (1), 2020, 151-157

[10] H. Li, Y. Wang, Y. Zhu, X. Xu, A. Wu, and X. Deng. 2018. Bambo derived magnetic carbonaceuos solid acid catalyst for the conversion of corncob into furfural promoted by warm water immersion. BioResouces, 13(3), 6221-6237.

[11] I. Mochida, S.H. Yoon, and W. Qiao, Catalyst in syntheses and carbon procusors, J. Brazil Chem. Soc. 17 (6), 2006, 1059-1073.

[12] X.C. Zhao, J. Wang, C.M. Chen, Y.Q. Huang, A.Q.Wang, and T. Zhang, Graphene oxide for cellulose hydrolysis: how it works as a highly active catalyst, Chemical Communication ,50, 2014, 3439 - 3442.

[13] H.H. Mardiah, H.C. Ong, H.H. Masjuki, S. Lim, Y.L. Pang, Investigation of carbon based solid acid catalyst from Jatropha curcas biomass in biodiesel production, Energy Conversion and Management, 144, 2017, 10 - 17.

[14] A.D.C. Fraga, C.P.B., Quirete, V.L. Ximenes, , E.F. Sousa-Aguiar, I.M. Fonseca, and A.M.B. Rego, Biomass derived solid acid as effective hydrolysis catalysts. Journal of Molecular Catalysts A: Chemical, 442, 2016, 248-257.

[15] W. Namchot, N. Panyacharay, W. Jonglertjunya, and C. Sakdaronnarong, Hydrolysis of delignified sugarcane bagasse using hydrothermal technique catalyzed by carbonaceous acid catalyst. Fuel, 116, 2014, 608 - 616.

[16] S. Li, Z, Gu, B.E, Bjorson, and A. Muthukumarappan, Biochar Based Solid Acid Catalyst Hydrolyze Biomass. Journal of Environmental Chemical Engineering, 1, 2013, $1174-1181$. 
[17] R. Ormsby, J.R. Katsner, and J. Miller, Hemicellulose hydrolysis using solid acid catalysts generated from biochar, Catalysis Today, 190, 2012: 89-97.

[18] Taslim, O. Bani, Iriany, N. Aryani, and G.S. Kaban, Preparation of activated carbon-based catalyst from candlenut shell impregnated with $\mathrm{KOH}$ for biodiesel production, Key Engineering Materials, 777, 2018, 262267.

[19] N.T, Abdel-Ghani, G.A. El-Chaghaby, M.H. El-Gammal, E.S.A. Rawash, Optimizing the preparation conditions of activated carbons from olive cake using $\mathrm{KOH}$ activation. New Carbon Materials volume, 31, 2016, 492-500.

[20] M. Kwiatkowski, D. Kalderis, E. Diamadopoulos. Numerical analysis of the influence of the impregnation ratio on the microporous structure formaton of activated carbon, prepared by chemical activation of waste biomass with phosphoric acid, J. Phys. Chem. Solids, 105, 2017, 81-85.

[21] L. N Rao and L. Al-Mukahini, Extraction of furfural $\left(\mathrm{C}_{5} \mathrm{H}_{4} \mathrm{O}\right)$ from waste bagasse of agricultural source. Journal of chemical and pharmaceutical research, 11(4), 2019, 17-28.

[22] X. Li, Q. Liu, L. Peng, R. Liu, Y.Y. Li, and X. Lan, Furfural produced from bamboo by a 2-step method at atmospheric pressure. Journal of chemical and pharmaceutical research, 6(5), 836-842.

[23] J.EOGuche, A.O. Ameh, Y. Tanimu, dan S.A. Egu, Determination and optimization of effect of process parameters on furfural yield from microalgae, $F U W$ Trends in Science and Technology Journal , 2(2),2017, 782-787.

[24] P. Luo, Y. Zhang, Y. Suo, Z. Liao, Y. Ma, H. Fu, and J. Wang, The global regulator IrrE from Deinococcus radiodurans enhances the furfural tolerance of Saccharomyces cerevisiae, Biochemichal Engineering Journal, 136, 2018, 69-77.

[25] J.H. Van der Maas, 1972. Basic Infrared Spectroscopy. Second edition, (New York: Heyden \& Son Inc., 1972).

[26] National Institute of Advanced Industrial Science and Technology (AIST), Furfural. https://www.aist.go.jp/index_en. html, 1999.

[27] M. Winfough, K. Voronova, G. Muller, G. Laguisma, B. Sztaray, A. Bodi, dan G. Meloni, Furfural: the unimolecular dissociative photoionization mechanism of the simplest furanic aldehyde, The Journal of Physical Chemistry, 12, 2017, 3401-3410. 